\title{
Technology-Related Involvement: The Effect Of The MASHOV System On Parent Involvement In Israeli Junior Highs
}

Prof. Nitza Davidovitch, Ariel University, Israel

Dr. Roman Yavich, Ariel University, Israel

\begin{abstract}
The purpose of the study was to examine differences in parental involvement between two high schools that use the MASHOV program (an online learning management system) and one high school where parents receive updates regarding their children in other ways, with attention to parents' background variables: sex, income, and schooling. The study shows that the MASHOV has a positive impact on parental involvement - parents who use the MASHOV program consistently demonstrate a high and significant level of involvement compared to parents who do not have access to this program. Parent involvement was also found to have a positive effect on the child's academic achievements, where the higher the level of involvement the higher the evaluation of the student's achievements. Furthermore, a difference was found between parent involvement in the school by sex. Mothers received a higher score for involvement than fathers. No significant correlation was found between parents' schooling and involvement. The research findings show that the growing trend in recent years whereby computerized systems, and in particular the computerized MASHOV program used in high schools, are being integrated in many educational institutions in order to reach effective pedagogic management, is proving efficient and important.
\end{abstract}

Keywords: Parent Involvement; Online Learning Management System; Student Achievements

\section{INTRODUCTION}

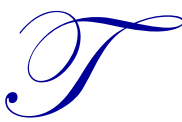

he introduction of the MASHOV system in high schools is perceived as an essential technological change in Israeli society. MASHOV - a Hebrew acronym for Promptness, Transparency, and Monitoring and literally meaning "feedback" - is a learning-management system that emphasizes organizational aspects as well as gathering computerized and processed information about learners and enables parents to receive direct and immediate updates on children's academic achievements, class attendance, behavior towards teachers and peers, etc. The system helps the educational staff arrange the data in a more controlled and organized manner and requires them to complete reports and enter data in real time, while also providing information about class averages, gathering and processing school data, and letting them choose their pedagogical activities accordingly.

Use of learning management systems in educational institutions is aimed not only at meeting teaching and learning goals. Some of these systems function as a new channel for interaction and communication (Blau \& Hameiri, 2010; Georgouli, Skalkidis \& Guerreiro, 2008).

\section{Parent Involvement in the Schools - Definition}

The research literature has offered different definitions for the term parent involvement. Some researchers claim that including parents in their child's educational and academic world should be perceived as a way of life in all areas rather than a one-time act (Waxman Fisher, 1998). In other words, the inclusion process is based on several 
principles that maintain a mutual relationship between parents and their children. Implementation of one principle might clash with another. Sometimes disagreement on inclusion principles and restriction of the principles to the theoretical level leads to non-inclusion of parents, i.e., lack of involvement. Hence, inclusion processes must be compatible with other major processes at the school, such as the principal-teacher relationship. Disagreement on inclusion principles can be explicit or implicit, by one side or both, passive or active. Principles cannot be accepted only in theory and their acceptance is tested by their implementation in the school's daily life.

Thus, parent involvement and inclusion is not just another process aimed at improving the school climate rather it is part of a way of life based on democratic principles.

- $\quad$ Researchers (Greensfeld, Alon \& Feldman, 2014) point out the significant correlation between involvement and three background variables: schooling, income, and town of residence. The study focuses on the effect of the variables on reported involvement. Educated parents were found to be less involved than uneducated parents with regard to teachers, achievements, and teaching methods. A significant correlation was also found between income and involvement: low-income parents were more involved than medium- and highincome parents with regard to achievements and teaching methods. Another correlation found was between respondents' town and involvement: urban parents were found to be more involved than rural parents with regard to teachers, achievements, and teaching methods.

- $\quad$ Fisher \& Friedman (2009) found a distinction between active and passive involvement of parents. Passive involvement is defined as parents who are not overtly active in the school, but are still "involved". They know about and are familiar with the pedagogic contents and social relationships and they are also familiar with decisions reached at the school. They are part of school events, but as covert partners.

In contrast, active involvement is overt and manifested in actual operations at the school. The findings show that parents who feel that the principal and teachers include them and display respect and trust towards them and their children, will have a higher probability of being actively or passively involved in the school's work. The study also shows the great significance of parents' identification with the concept of the school being an important factor that helps students attains a better life in the future, as evident both in their active and their passive involvement. The more parents believe in the significance of the school and of the teachers, the more actively or passively involved they are in the school's work.

- $\quad$ Friedman \& Fisher (2002) sought to reveal the factors and conditions that might explain different levels of parent involvement in the school, whether active or passive, and for this purpose they studied the contribution of the variables of involvement, perceived inclusion, and displays of trust in parents, to predicting parent involvement in school life. These factors have in common the wish to reduce the disparity between home perceptions and school perceptions. Parents' influence on the school depends on their pattern of involvement. The researchers also emphasize that collaboration between the school and the parents is an inseparable part of creating a positive school climate, which contributes to increasing motivation to learn and improved academic, educational, social, ethical, and community achievements. The paper found that the most prominent predictor of active and passive parent involvement in school life is the school's trust in parents. Other predictors found were parents' identification with the importance of studies at the school and with the goals and values imparted by the school. Furthermore, of all parents' background variables, sex, schooling, and country of origin were found to be the best predictors of active involvement. Passive involvement was predicted only by parents' schooling.

In summary, parent involvement is indeed a significant concept with a considerable effect on the child. On the other hand, it was found to be dependent on and influenced by many variables. In this study we shall try to control these variables in order to uncover the effect of the MASHOV program on parental involvement in Israel.

\section{MASHOV - Feedback}

John Hattie, a well-known researcher in the area of classroom feedback (Hattie \& Timperley, 2007), conducted a meta-analysis to examine the effect of different variables on student achievements. The study included variables such as: pattern of teaching, method of evaluation, classroom size, students' prior knowledge, climate, and more. The study shows that the most significant variable is oral and written feedback given to students on their performance and that it had the most influence on their achievements. 
1.

The five most influential variables on students' achievements, by order of influence, are presented in Table

Table 1. The five most influential variables on students' achievements

\begin{tabular}{lcl}
\hline \multicolumn{1}{c}{ Variable } & Level of influence & Depends on.. \\
\hline Feedback & 1.13 & Teacher and student \\
Prior knowledge & 1.04 & Student \\
Quality of instruction & 1.00 & Teacher \\
Motivation & 0.61 & Student \\
Classroom climate & 0.56 & Teacher \\
\hline
\end{tabular}

Moreover, according to this study there is a distinction between feedback perceived as promoting learning (promotes students' understanding and develops thinking) and feedback that does not promote learning (does not provide sufficient information on demands made of students and how to correct or complete tasks effectively and positively).

- The data showed that when a large amount of data was entered in the system by teachers this increased online interactions by families as well as the number of student entries. The rate of technology adoption among parents was higher than in a class where the MASHOV website was updated less often.

- $\quad$ This study also found gender differences in patterns of parental involvement. Compared to fathers, mothers accessed the online system more often, adopted the technology faster, and also took advantage of the teacher's willingness to update the data on a daily basis in order to remain up to date concerning their children.

In summary, technology has a significant effect on parent involvement in their children's school in the modern era. This effect is evident in almost all fields of life. The current study attempts to examine the technological impact on the nature of relationships between older and younger population groups, with reference to parental involvement with their children in the pedagogical field. The question that will guide the study procedure is whether and to what degree did technology improve the parent-child relationship, or did it increase their alienation?

\section{THE METHOD}

\section{Sample}

The population we chose to study are parents of high school students, Israelis who live mainly in southern and central Israel, with a distinction between parents who use the MASHOV system and those who don't. The distinction was made through a preparatory question asked by the researcher.

The study included two rounds:

1. In the first round questionnaires were administered manually to 140 respondents, including 70 parents who receive updates through the MASHOV program that informs them of their child's progress at school and 70 parents who receive information from other non-online sources. In southern Israel the questionnaire was administered mainly to parents of students in the AMIT high school in Beer Sheva who use the MASHOV system.

2. In the second round the questionnaires were administered online to 100 respondents from a school in central Israel.

\section{The Research Tool}

The efficiency of the MASHOV program as affecting parental involvement in school events was examined through a questionnaire based on Yael Waxman Fisher's $\mathrm{PhD}$ dissertation on "Identification, awareness, and perceived accessibility as predictors of parental school involvement" (1998). The questionnaire was anonymous and 
aimed at clarifying the mutual relations between parents and their children's school. The questionnaire included 32 questions (statements):

The first questions (1-6) were intended to detect variables that might influence the research results and that could be perceived by respondents as more personal questions, such as: sex, parent's income, frequency of parentteacher relationship, parent's schooling, and parent's perception of the child's academic achievements as well as of the child's behavior at school.

The rest of the questionnaire (questions 7-32) includes statements reflecting the parent's involvement. For each statement the parent was requested to rank the frequency of the statement for him/her.

Replies were on a four-point scale, ranging from "1=never" to "4=always". Before completing the questionnaire the parent was asked by the researchers whether the MASHOV system is integrated in his/her child's high school.

The research procedure: In the first round we entered the MASHOV system and checked which schools use the system. We contacted various schools to receive their help with administration of the questionnaire. Notably, in the data collection stage we did not encounter any irregular parent reactions and most responded positively and demonstrated a high willingness to participate and to help with the study. In the second round the questionnaire was administered online with Google Drive, with the cooperation of the school principal.

\section{Research Hypotheses}

- A positive relationship will be found between use of the MASHOV program and parent involvement.

- A positive relationship will be found between parents' reported involvement and their perception of their children's school achievements.

\section{Findings}

In the first round, in order to examine our first hypothesis we performed a t-test for independent samples. The results of the test show that the score for parental involvement in schools with the MASHOV system $(\mathrm{M}=75.78)$ is higher than for parental involvement in schools without the MASHOV system $(\mathrm{M}=64.42)$. The results of the test are: $\mathrm{p}>0.001 \mathrm{t}(129)=7.228$.

Table 2 presents a general involvement score through a display of all the questions (a total of 26 questions) and it shows that the score ranges from 25-100.

Table 2. Group Statistics: General involvement score (H1)

\begin{tabular}{llccc}
\hline $\begin{array}{c}\text { With or Without } \\
\text { MASHOV }\end{array}$ & $\mathbf{N}$ & Mean & Standard deviation & Mean standard error \\
\hline With MASHOV & 69 & 75.78 & 7.46338 & 0.89849 \\
Without MASHOV & 63 & 64.42 & 10.98843 & 1.38441 \\
\hline
\end{tabular}

Table 3. Independent Samples Test: Test for equality of means

\begin{tabular}{|c|c|c|c|c|c|c|c|c|}
\hline & \multicolumn{4}{|c|}{ Levene's test for equality of variances } & \multicolumn{4}{|c|}{ Test for equality of means } \\
\hline & $\mathbf{F}$ & SIG & $\mathbf{T}$ & DF & $\begin{array}{c}\text { Mean } \\
\text { difference }\end{array}$ & $\begin{array}{l}\text { Std. error } \\
\text { difference }\end{array}$ & $\begin{array}{r}95 \% \text { conf } \\
\text { of the }\end{array}$ & $\begin{array}{l}\text { ce interval } \\
\text { erence }\end{array}$ \\
\hline & & & & & & & Lower & Upper \\
\hline $\begin{array}{l}\text { Equal variances } \\
\text { assumed }\end{array}$ & 7.481 & 0.007 & 6.713 & 130 & 10.89372 & 1.62278 & 7.68325 & 14.10419 \\
\hline $\begin{array}{l}\text { Equal variances not } \\
\text { assumed }\end{array}$ & & & 6.601 & 107.792 & 10.89372 & 1.65042 & 7.6224 & 14.16520 \\
\hline
\end{tabular}


In addition, in order to examine the differences in involvement between mothers and fathers another t-test for independent samples was performed. The results of the test, show that the score for mothers' involvement $(\mathrm{M}=72.24)$ is higher than for fathers' involvement $(\mathrm{M}=67.21)$. The results of the test are: $\mathrm{p}<0.001,2.643-\mathrm{t}(129)$.

Table 4. Group Statistics: Differences in involvement between mothers and fathers (H2)

\begin{tabular}{lcccc}
\hline \multicolumn{1}{c}{ Respondent's sex } & N & Mean & Std. deviation & Mean standard error \\
\hline Male & 43 & 67.21 & 11.769 & 1.795 \\
Female & 88 & 72.24 & 9.612 & 1.025 \\
\hline
\end{tabular}

Table 5. Independent Samples Test: Test for equality of means

\begin{tabular}{|c|c|c|c|c|c|c|c|c|}
\hline & \multicolumn{4}{|c|}{ Levene's test for equality of variances } & \multicolumn{4}{|c|}{ Test for equality of means } \\
\hline & $\mathbf{F}$ & SIG & $\mathbf{T}$ & DF & $\begin{array}{c}\text { Mean } \\
\text { difference }\end{array}$ & $\begin{array}{l}\text { Std. error } \\
\text { difference }\end{array}$ & $\begin{array}{r}95 \% \text { con } \\
\text { of th }\end{array}$ & $\begin{array}{l}\text { e interval } \\
\text { rence }\end{array}$ \\
\hline & & & & & & & Lower & Upper \\
\hline $\begin{array}{l}\text { Equal variances } \\
\text { assumed }\end{array}$ & 1.594 & 0.209 & 2.283 & 129 & -4.401 & 1.928 & 8.217 & 0.586 \\
\hline $\begin{array}{l}\text { Equal variances not } \\
\text { assumed }\end{array}$ & & & 2.130 & 70.236 & -4.401 & 20067 & 8.523 & 0.280 \\
\hline
\end{tabular}

In order to examine the third hypothesis concerning the correlation between parent's involvement and children's achievements, a Spearman correlation was performed. The test results show a positive correlation $(\mathrm{sr}=0.239, \mathrm{p}>0.01)$, such that the higher the level of involvement the higher the evaluation of the student's achievements.

Table 6. Spearman's Correlation: Children's academic achievements (H3)

\begin{tabular}{lccc}
\hline & & Involvement Score & $\begin{array}{c}\text { How would you define your child's } \\
\text { academic achievements in the past year? }\end{array}$ \\
\hline Score Involvement & Correlation coefficient & 1.000 & 0.252 \\
& $\mathrm{Sig}$ & 132 & 0.002 \\
& $\mathrm{~N}$ & 0.252 & 132 \\
\hline How would you define your & Correlations coefficient & 0.002 & 1.000 \\
child's achievements in the & $\mathrm{Sig}$ & 132 & 132 \\
past year? & $\mathrm{N}$ & & \\
\hline
\end{tabular}

** Correlation is significant at the 0.01 level

In order to examine the relationship between parents' schooling and their involvement score we performed a Spearman correlation. No significant correlation was found between the variables.

Table 7. Relationship between parents' schooling and their involvement score

\begin{tabular}{lccc}
\hline & & Involvement score & Parents' schooling \\
\hline Involvement score & Correlation coefficient & 1.000 & 0.067 \\
& $\mathrm{Sig}$ & & 0.221 \\
& $\mathrm{~N}$ & 132 & 132 \\
\hline Parent's schooling & Correlation coefficient & 0.067 & 1.000 \\
& $\mathrm{Sig}$ & 0.221 & 132 \\
\hline
\end{tabular}

** Correlation is significant at the 0.01 level

\section{Main Findings of the First Round}

A significant positive correlation was found between the variables, i.e., the MASHOV program was found to have an effect on parent involvement. Accordingly, the findings show that parents who use the MASHOV program consistently display a high and significant level of involvement $(\mathrm{M}=87.57)$ versus parents who do not have access to this program $(\mathrm{M}=24.46)$. Our findings are similar to previous findings (Epstein, 1995; Henderson \& Berla, 1994). 
It is also clear that the parent's involvement has a positive effect on the child's academic achievements. The test results show a positive relationship $(\mathrm{sr}=0.239, \mathrm{p}>0.01$ ), such that the higher the level of involvement the higher the evaluation of students' achievements. Similarly, a correlation with the parent's gender was also found (Lamb, $2000,2010)$. A difference was found between the involvement of parents by sex. The test results show that mothers' involvement score $(\mathrm{M}=42.27)$ was higher than fathers' $(\mathrm{M}=12.76)$.

The study shows no significant effect of parents' schooling.

\section{Main Findings of the Second Round}

Participants consisted of 99 parents, $45 \%$ men and 55\% women. Fifty nine percent had a post-secondary education, $19 \%$ a high school education, $18 \%$ a partial high school education, and $4 \%$ had no post-primary education.

The parents evaluated their child's behavior at school. Eleven percent defined the behavior as problematic, $13 \%$ as reasonable, $21 \%$ as good, and $55 \%$ as very good.

Nine percent of the parents assessed their monthly income as low, $24 \%$ defined it as average, $33 \%$ assessed it as high, and the same percent (33\%) as very high.

Twelve percent of the parents defined their child's academic achievements in the past year as very bad (grades of $50-60$ ), $8 \%$ as medium (grades of $61-70$ ), $33 \%$ as good (grades of $71-80$ ), and $46 \%$ as high (grades of 81 $100)$.

With regard to contact with their child's homeroom teacher, $20 \%$ of the parents reported daily contact, $22 \%$ weekly contact, $37 \%$ stated contact on a monthly basis, and $20 \%$ of parents stated that they are in contact with the homeroom teacher once a year.

Table 8. Parent-school contact

\begin{tabular}{|c|c|c|c|c|}
\hline Statements evaluating parent-school contact & Never & Rarely & Frequently & Always \\
\hline I am aware of the achievements of all students in the class & $21 \%$ & $25 \%$ & $26 \%$ & $27 \%$ \\
\hline I am familiar with the teachers and homeroom teachers & $6 \%$ & $29 \%$ & $34 \%$ & $30 \%$ \\
\hline I am familiar with social relationships in the class & $11 \%$ & $36 \%$ & $25 \%$ & $27 \%$ \\
\hline I am familiar with the social activities conducted in the class & $6 \%$ & $18 \%$ & $34 \%$ & $30 \%$ \\
\hline I am familiar with my children's study programs & $18 \%$ & $16 \%$ & $35 \%$ & $30 \%$ \\
\hline I am aware of problems with violence at the school & $27 \%$ & $17 \%$ & $24 \%$ & $31 \%$ \\
\hline The school includes me in its decisions & $25 \%$ & $15 \%$ & $30 \%$ & $29 \%$ \\
\hline I take an active part in the parents' committee in my children's class & $14 \%$ & $32 \%$ & $30 \%$ & $23 \%$ \\
\hline I meet with the school principal about relevant subjects & $21 \%$ & $27 \%$ & $26 \%$ & $25 \%$ \\
\hline I receive help from the school when necessary & $20 \%$ & $23 \%$ & $33 \%$ & $23 \%$ \\
\hline $\begin{array}{l}\text { My children's teacher consults with me as a parent on educational } \\
\text { matters }\end{array}$ & $21 \%$ & $31 \%$ & $23 \%$ & $24 \%$ \\
\hline I agree with the school's goals, striving for high achievements & $12 \%$ & $19 \%$ & $28 \%$ & $40 \%$ \\
\hline $\begin{array}{l}\text { I emphasize to my children that the teachers' instructions should be } \\
\text { followed }\end{array}$ & $12 \%$ & $16 \%$ & $30 \%$ & $41 \%$ \\
\hline I identify with the life style taught by the school & $11 \%$ & $20 \%$ & $37 \%$ & $31 \%$ \\
\hline I expect my children's teacher to know how to approach them & $9 \%$ & $27 \%$ & $27 \%$ & $36 \%$ \\
\hline I agree and accept the customary teaching methods at the school & $12 \%$ & $24 \%$ & $28 \%$ & $35 \%$ \\
\hline I agree with the school's instilling of values & $12 \%$ & $24 \%$ & $19 \%$ & $44 \%$ \\
\hline I am aware of my child's responsibilities and rights at school & $16 \%$ & $14 \%$ & $28 \%$ & $41 \%$ \\
\hline I am aware of how the school's students dress and of their appearance & $14 \%$ & $15 \%$ & $38 \%$ & $32 \%$ \\
\hline I am aware of my child's number of absences and tardiness in class & $9 \%$ & $15 \%$ & $28 \%$ & $47 \%$ \\
\hline I see myself as an inseparable part of the educational process & $12 \%$ & $11 \%$ & $35 \%$ & $41 \%$ \\
\hline I keep abreast of my child's achievements independently & $20 \%$ & $20 \%$ & $25 \%$ & $34 \%$ \\
\hline To what degree does your child share school events with you & $7 \%$ & $17 \%$ & $27 \%$ & $48 \%$ \\
\hline I am well aware of my child's exam dates & $6 \%$ & $15 \%$ & $26 \%$ & $42 \%$ \\
\hline
\end{tabular}




\section{DISCUSSION AND CONCLUSIONS}

Parent involvement is gradually becoming a main topic of research in the social and pedagogical domains. Research findings on academic achievements consistently show that this process is affected by parent involvement (Epstein, 1995; Henderson \& Berla, 1994).

At the same time, technological developments have major significance and effects on many areas of our life, and in the academic areas as well.

The current study examined the difference in parental involvement between parents who use the MASHOV program and parents who do not.

According to the findings of this study, a significant positive relationship was found between the variables, i.e., the MASHOV program was found to have an effect on parental involvement. A possible explanation of this finding is that when parents demonstrate maximal interest beyond that expected of them (not only in formal parentteacher conferences or emergency telephone calls) the child feels a certain commitment to refrain from disappointing the parent. Furthermore, due to the increasing exposure and competition in the current era, children know that other parents post their impressions and respond on the social networks and therefore make more of an effort to be a source of pride and upgrade their achievements and status (with regard to grades, versus classmates) through technological means.

In an attempt to find other differences, the study examined the hypothesis that parents' sex affects their level of involvement. Analysis of the results shows that such a difference exists, where mothers' involvement is higher than fathers'. This trend leads to the conclusion that gender has a great deal of influence on parental involvement in education.

The hypothesis that parental involvement has a positive effect on the child's academic achievements was confirmed. A possible reason is the child's sense of commitment when the parent displays caring and attaches significance to academic issues. This can also be related to the teacher's attitude to a child whose parents are constantly alert. Teachers can't in good conscience avoid doing everything they can to help such children succeed due to the commitment they feels towards the devoted parents who are usually busy with their own work and career and bear a great deal of responsibility.

No correlation was found between the parent's schooling and involvement in school events. Parents with a high level of education may occupy key positions at work. Hence, their own education is manifested in their career. Whether their children's studies are perceived as important or not they cannot find time to receive daily updates due to their responsibilities stemming from their education and job proficiency. However, this may also be true of parents who have received little schooling and who are burdened by the need to support their family, leaving no time for considerable involvement in their children's school activities, and they assume that at school the child is under the responsibility of the teachers and the parents will care for him at home.

The main limitation of this study is that the data collection procedure involved a self-administrated questionnaire, possibly perceived as not objective to a certain degree. Also potentially problematic is the fact that while the questionnaire was being completed the researchers were present in the room. This might have affected respondents' answers, with regard to the pressure they felt at the time or social desirability.

This study reveals additional aspects of the difference between types of parents and their current involvement in their children's life in the academic sphere. The literature studied differences between parents' features and discussed the various variables.

This study is unique. Its findings show that technological progress has an effect on both family and pedagogical relationships and that there is indeed a disparity between parents who use the MASHOV program and those who do not. Accordingly, it may be claimed that children of parents who use the MASHOV program will feel 
more of a need to fulfill their parents' expectations due to the involvement displayed by the latter. In summary, most of the results of this study reflected positive correlations but some of these were not significant.

This study has potential contributions for technological developments with regard to pedagogy in general and parental involvement in particular. Its major anticipated contribution is to the enrichment of parents' and teachers' awareness of the significance of parental involvement and the exposure of parents and teachers to the positive technological impacts in this area.

As researchers, we strive to try and effect social change by raising the awareness of Israeli parents concerning the significance of involvement while also increasing teachers' motivation to encourage involvement and to share matters that concern academic and social contents with students and parents. This will encourage all Israeli children to reach better academic goals and self-fulfillment.

The very differences found reflect the significance of involvement and of technological progress and stress that proper well-planned use of technology is capable of facilitating the success of every child and advancing the success and excellence of Israeli society.

\section{ACKNOWLEDGEMENTS}

Thanks to Grace Ganor and Aviv Moatty, whose seminar paper written under my supervision formed the basis for this paper.

\section{AUTHOR INFORMATION}

Prof. Nitza Davidovitch (d.nitza@ariel.ac.il) serves in teaching and administrative positions and is the Head of Quality Assessment and Academic Instruction at Ariel University; she is also the head of the Israeli Forum of Faculty Development Centers.

Areas of interest include: academic curriculum development; development of academic instruction; Holocaust awareness and Jewish identity; director of student exchange programs with Germany and Poland; preservation of the heritage of Jewish sects; and moral education.

Academic administration: Leader of academic assessment process at the Ariel University on behalf of the CHE. Initiation and development of national and international academic collaboration. Curriculum development and Development of curricula for special-needs populations.

Dr. Roman Yavich (romany@ariel.ac.il) specializes in informatics. He deals with the use of Internet technologies in the educational process. Dr. Yavich is the author of the technical support concept in the Internet MathOlympiad organization.

Responsible for Computing Systems Support of the Faculty of Natural Sciences, Ariel University. He is a member of the Steering Committee of the Israel Mathematical Olympiad (on behalf of the Ministry of Education).

Areas of interest include: Distance Education, ELearning, Networked, Education, Pedagogy

Academic administration: Referent of E-learning-Professional consultation for all the Faculties and Departments, in the field of E-learning, developing computer based training software and computers use in teaching process improvement. 


\section{REFERENCES}

Blau, I. \& Hameiri, M. Implementing technological change at schools: Promoting online interactions at schools through "Mashov" learning management system. In: Y. Eshet-Alkalai, A. Caspi \& S. Eden (Eds.), Learning in the Technological Era. Ra'anana, Israel: Open University of Israel. [Hebrew]

Friedman, I. (2010). School-parent relationships in Israel, background material for the initiative project. [Hebrew]

Friedman, I. \& Fisher, Y. (2002). Identification and awareness: Basis of parental involvement in school work. Studies in Education Administration and Organization, 26, 6-33. [Hebrew]

Friedman, I. \& Fisher, Y. (2009). Parents and school: Mutuality and involvement. Dapim, 40-47 [Hebrew]

Greensfeld, H., Alon, R. \& Feldman, D. (2014). Literature review on: Current knowledge on beneficial relationships between schools and families of children with special needs and on intervention programs developing these relationships. Research Center, Michlala Jerusalem. Available at: http://education.academy.ac.il/Uploads/BackgroundMaterials/Hebrew/Greensfeld-Alon-Feldman.pdf [Hebrew]

Hattie, J. \& Timperley, H. (2007). The power of feedback. Review of Educational Research 77(1), 81-112.

Waxman Fisher, Y. (1998). Identification, awareness and perceived accessibility as predictors of parental school involvement. Doctoral dissertation, Hebrew University. [Hebrew] 
NOTES 